\title{
A Democratização do Ensino Fundamental no Município de Guaratuba
}

\author{
Autor: Rosana de Fátima Silveira Jammal \\ Nível: Mestrado (PPGE/UFPR) \\ Orientadora: Profa. Dra. Taís Moura Tavares
}

\begin{abstract}
Esta pesquisa tem como intenção compreender a democratização, em processo, do ensino fundamental, primeiras séries, no município de Guaratuba. Isso, através da avaliação da política em seu operando, a partir da observação do investimento, condições de qualidade e resultado de desempenho (neste caso o IDEB) como elementos co-dependentes. A suposição que se faz é que a co-dependência, entre as variáveis: financiamento, condições de qualidade e resultado de desempenho, interfira no processo de democratização do ensino. E que essa co-dependência revele o quanto se avança nesse processo e quais as limitações que têm sido impostas. As hipóteses levantadas são: i) em nível municipal, o investimento (a partir dos dispositivos legais CF e Lei 9424/96) em educação fica atrelado à arrecadação própria e de transferência, e automaticamente ao pouco ou ao muito que se arrecada; ii) o que se arrecada não é suficiente para dar conta de lidar com todos os condicionantes da qualidade em educação; iii) a gestão municipal interfere diretamente nos destinos do investimento (apesar das amarras legais) em educação e isso pode comprometer as condições de qualidade positivamente e negativamente; iv) o IDEB é um referencial que se
\end{abstract}

\begin{abstract}
correlaciona com os condicionantes de qualidade e o investimento em educação, no município de Guaratuba. O trabalho é apresentado em três capítulos, no primeiro, a título de apresentação, contextualiza-se o tema políticas educacionais: comentam-se as teses debatidas, observa-se a história da estruturação do estado nacional, a centralização e descentralização de poderes neste estado, um pouco da história da tributação e da reforma estatal nos anos noventa. No segundo capítulo, trata-se do objeto da pesquisa e da metodologia. No terceiro capítulo, realizase a avaliação da democratização do ensino fundamental, nas primeiras séries, no município de Guaratuba; analisam-se investimento em educação, condições de qualidade ofertadas, em âmbito municipal e resultado de desempenho obtido no IDEB de 2007; para, então, avaliarse o processo de democratização ocorrido no município. A conclusão da pesquisa é que a relação de co-dependência existe e pode ser observada, quando se analisam as variáveis: financiamento, condições de qualidade e resultados de desempenho conjuntamente; e, que o que aparece mais nitidamente como limitador da democratização do ensino fundamental, séries iniciais, é o modelo de gestão adotado.
\end{abstract}

Palavras-chaves: políticas educacionais, democratização, ensino fundamental. 